\title{
KYBERÚTOK AKO VNÚTORNÁ INFORMÁCIA ALEBO KEDY S PRAVDOU VON
}

\author{
TOMÁŠ ABELOVSKÝ"
}

\begin{abstract}
ABSTRAKT
Nasledujúca úvaha sa snaží zodpovedat na otázku, kedy a či vôbec má tuzemský emitent finančného nástroja uverejnit informáciu o kyberútoku na jeho informačný systém. ${ }^{1}$ Sú analyzované otázky notifikačnej povinnosti o vnútornej informácii. Úvaha smeruje $k$ záveru, že emitent má povinnost' bezodkladne informovat' o prebiehajúcom alebo dokonanom kyberútoku relevantnú verejnost', ak sú splnené niektoré podmienky kladené na kvalitu vnútornej informácie.
\end{abstract}

\section{KLÚČOVÉ SLOVÁ}

kyberútok, vnútorné informácie, oznamovacia povinnost', emitent finančného nástroja

\section{ABSTRACT}

The following paper answers the question when and whether a domestic issuer of a financial instrument should disclose an information about a cyberattack against his system. The paper analyses a notification duty about insider information. The reasoning concludes that if certain requirements for the quality of insider information are met, the issuer has an obligation to inform the relevant public without delay about ongoing or completed cyberbattack.

\footnotetext{
Mgr. Tomáš Abelovský je doktorand na Ústave práva a technológií, Právnickej fakulty Masarykovej Univerzity. Kontaktný e-mail je tomas@abelovsky.com.

1 Úvaha je riešená vo svetle českej, ale aj slovenskej právnej úpravy vnútorných informácií.
} 


\section{KEYWORDS}

Cyberattack, insider information, notification obligation, issuer of a financial instrument

\section{1. ÚVODNÉ POZNÁMKY}

V marci 2016 došlo ku masívnemu kyberútoku na viaceré americké advokátske kancelárie, ktoré zastupujú najväčšie verejne obchodovatel'né korporácie (Cravath, Weil Gotshal). ${ }^{2}$ Zaujímavostou tohto útoku je, že na rozdiel od nedávneho prípadu odcudzenia množstva kreditných kariet a osobných údajov z banky JP Morgan Chase, ${ }^{3}$ tento učebnicový hackerský útok smeroval k získaniu dôverných a vnútorných informácií klientov. Účelom bola ich analýza a následné zobchodovanie. Držanie vnútornej informácie a vyčkávanie na jej vhodné použitie má niekol'ko následkov. Za prvé, táto taktika útočníkov stažuje prácu orgánov činných v trestnom konaní. Za druhé, následok tohto činu je nekontrolovatel'ný, no najmä v prípade neochoty advokátskych kancelárií informovat o útoku svojich klientov alebo verejnost'. V USA tento prípad otvoril diskusiu o tom, či má právny zástupca verejne obchodovatel'ných spoločností informovat širokú verejnost' v prípade kyberútoku. ${ }^{4}$ Takáto povinnost̉ sa už však dávno vztahovala na subjekty regulované Americkou komisiou pre cenné papiere a burzu (SEC). ${ }^{5}$ Nasledujúca krátka úvaha sa snaží zodpovedat na otázku, kedy a či vôbec

HONG, N. a Sidel, R., Hackers Breach Law Firms, Including Cravath and Weil Gotshal. The Wall Street Journal. Marec 2016. Dostupné z: http://www.wsj.com/articles/hackers-breachcravath-swaine-other-big-law-firms-1459293504

3 What lies behind the JPMorgan Chase cyber-attack. The Economist. November 2015. Dostupné z: http://www.economist.com/news/business-and-finance/21678214-criminal-economy-developing-faster-lawful-one-can-defend-itself-what-lies-behind

447 štátov má vlastnú legislatívu týkajúcu sa porušenia osobných údajov (security breach notification laws), ktorá ma pôvod v kalifornskej úprave. Vid' Cal. Civ. Code 1798.82 and 1798.29. Dostupné z: http://www.leginfo.ca.gov/pub/01-02/bill/sen/sb_13511400/sb_1386_bill_20020926_chaptered.pdf

5 Division of Corporation Finance, Securities and Exchange Commission, CF Disclosure Guidance. 2011. Dostupné z: https://www.sec.gov/divisions/corpfin/guidance/cfguidancetopic2.htm 
má tuzemský emitent finančného nástroja ${ }^{6}$ povinnost uverejnit informáciu o samotnom kyberútoku na jej informačný systém. ${ }^{7}$

\section{POVINNÁ OSOBA}

Zákon o podnikaní na kapitálovom trhu definuje širokú skupinu povinných osôb, ${ }^{8}$ ktoré majú notifikačnú povinnost', či už voči dozornému orgánu alebo verejnosti. Ako príklad môže poslúžit akciová spoločnost', ktorá je emitentom investičného nástroja obchodovaného na regulovanom trhu EÚ (napr. na Burze cenných papírů Praha). Táto obchodná korporácia má zákonnú povinnost’ bezodkladne zverejňovat’ a oznamovat tie vnútorné informácie, ktoré sa jej priamo týkajú. ${ }^{9}$ Je možné predpokladat, že emitent, ktorý má kapitálovú účast širšej verejnosti, si nesie dôležitú povinnosť čo najskôr informovat akcionárov alebo investorov o vnútorných informáciách, ktoré môžu mat̉ vplyv na cenu jej emitovaných finančných nástrojov (napr. akcií).

6 $\quad$ Emitentom je právnická osoba, ktorá sa riadi súkromným alebo verejným právom a ktorá emituje finančné nástroje alebo navrhuje ich emisiu, pričom emitent je v prípade depozitných certifikátov zastupujúcich finančné nástroje emitentom zastupovaných finančných nástrojov.

7 Právny problém bude analyzovaný vo svetle platnej právnej úpravy ČR (zákon č. 256/2004 Sb. o podnikání na kapitálovém trhu), SR (Zákon č. 566/2001 Z. z. o cenných papieroch a investičných službách a o zmene a doplnení niektorých zákonov, zákon č. 429/2002 Z. z. o burze cenných papierov v znení neskorších predpisov.) a najmä nariadenia Európskeho parlamentu a rady (EÚ) č. 596/2014 zo 16. apríla 2014 o zneužívaní trhu (nariadenie o zneužívaní trhu) a o zrušení smernice Európskeho parlamentu a Rady 2003/6/ES a smerníc Komisie 2003/124/ES, 2003/125/ES a 2004/72/ES. Český zákon používa pojem „vnitřní informace“ (§ 124), slovenský „dôverná informácia“ (§ 132b) a nariadenie „inside information“ (Article 7). Pre potreby tejto práce bude používaný promiscue pojem „dôverná informácia“ aj ked’ jeho význam v obchodnoprávnych vztahoch je odlišný. Vid”. KOTÁSEK, Josef. Ochrana vnitřních informací. Brno: Tribun EU, 2008. 255 s. ISBN 978-80-7399-355-9. Str. 77 an.

8 Napr. obchodník s cennými papiermi a inštitucionálny investor, organizátor regulovaného trhu, emitent cenných papierov, osoba podielajúca sa na rozhodovaní emitenta a osoby jej blízke, akcionár v špecifickej situácii, zamestnanci alebo iné osoby pri výkone svojho zamestnania, povolania alebo funkcie, alebo osoby v súvislosti s plnením svojich povinností na obchodoch $s$ investičnými nástrojmi.

9 § 132b odst. 1 zákona č. 566/2001 Z. z. o cenných papieroch a investičných službách a o zmene a doplnení niektorých zákonov, § 125 odst. 1 zákona č. 256/2004 Sb. o podnikání na kapitálovém trhu alebo článok 17 odst.1 nariadenia EÚ č. 596/2014 o zneužívaní trhu. 
Filozofia tejto úpravy spočíva v tom, že ide jednak o prevenčný boj s insider tradingom, ale rovnako aj záväzok kapitálovej spoločnosti voči svojím akcionárom, ale aj potencionálnym investorom. Spoločnost̉ môže svoje financovanie hl'adat na kapitálových trhoch - burzách, čo však nie je zvykom pre kontinentálne burzy na rozdiel od USA. Napokon aj prísna verejná regulácia emitenta (napr. akciovej spoločnosti) je znakom toho, že štát má záujem o transparentnost̉ obchodných transakcií takejto spoločnosti. Vyššie uvedená povinnost' trvá aj z dôvodu, že spoločnost̉ si potrebuje sústavne budovat vlastnú dôveru u svojich akcionárov, potencionálnych investorov, partnerov, zákazníkov a v neposlednom rade celého trhu ako takého.

Americká teória pri zákaze insider tradingu hovorí o fiduciárnej povinnosti voči investorom (akcionárom), resp. o rovnom a férovom prístupe k obchodovatel’ným nástrojom (equal access), ale aj o predchádzaní zneužitia takejto informácie (prípady Chiarella and Dirks). ${ }^{10}$ Je zrejmé, že táto teória ovplyvnila aj európsku reguláciu. Tá akcentuje zákaz transakcií zasvätených osôb (s výnimkami pre určité osoby a určité transakcie, v režime safe harbour), s určitými prvkami transparentnej evidencie (vedenie zoznamov zasvätených osôb, oznamovanie transakcií). ${ }^{11}$

\section{KYBERÚTOK AKO VNÚTORNÁ INFORMÁCIA}

Kyberútok je možné definovat ako čin s použitím počítača alebo súvisiacich technológií, siete alebo systémov, smerujúci k narušeniu, odcudzeniu alebo zničeniu informačného systému (resp. tam uložených dát) a majetku. Pre potreby tejto práce bude používaný zjednodušený pojem kyberútok. ${ }^{12}$

10 SCHEPPELE, Kim Lane. "It's Just Not Right": The Ethics of Insider Trading. Law and Contemporary Problems, Vol. 56, No. 3, Modern Equity, Summer, 1993. Str.124 an. alebo Ibid. KOTÁSEK, Str. 41 an.

11 Ibid. KOTÁSEK, Str. 51 an.

12 Český zákon o kybernetickej bezpečnosti rozoznáva kybernetickú bezpečnostnú udalost’ a incident. „Kybernetickou bezpečnostní událostí je událost, která může způsobit narušení bezpečnosti informací $\mathrm{v}$ informačních systémech nebo narušení bezpečnosti služeb anebo bezpečnosti a integrity sítí elektronických komunikací. Kybernetickým bezpečnostním incidentem je narušení bezpečnosti informací v informačních systémech nebo narušení bezpečnosti služeb anebo bezpečnosti a integrity sítí elektronických komunikací v důsledku kybernetické bezpečnostní události." Vid'. § 7 zákona č. 181/2014 Sb. o kybernetické bezpečnosti a o změně souvisejících zákonů (zákon o kybernetické bezpečnosti). 
Kyberútok voči súkromnej spoločnosti je väčšinou motivovaný nedovoleným obohatením na úkor napadnutej osoby. Trestný zákon definuje trestný čin neoprávneného prístupu $\mathrm{k}$ počítačovému systému alebo nosiču informácií pomocou prekonania bezpečnostného opatrenia a tým neoprávnené získanie prístupu k počítačovému systému alebo $\mathrm{k}$ jeho časti. ${ }^{13}$

Predmetom tohto činu v prípade akciovej spoločnosti môže byt široká paleta vnútorných informácií alebo osobných údajov, ktoré spravujú zasvätené osoby: ${ }^{14}$ napr. vnútorná databáza partnerov a ich platby, nezverejnené účtovníctvo a súvisiace správy, pripravované podnikatelské zámery a projekty, pripravovaný odpredaj podniku atd’. Je zrejmé, že každá z týchto informácií má potenciál ohrozit úplnú a riadnu transparentnost̉ trhu. Najmä v prípade, ak by sa dostala do rúk len niektorých účastníkov trhu (zneužívanie trhu). ${ }^{15}$ Základným motívom je zvyčajne obchodovanie s využitím týchto vnútorných informácií. Útočníkom môže byt externá osoba, ale aj zamestnanec, resp. zasvätená osoba emitenta. Zainteresované subjekty (napr. kupujúci vnútornej informácie) tak získavajú nespravodlivú výhodu na úkor poškodenej osoby na základe vnútornej informácie, o ktorej pred útokom nevedeli, a v dôsledku toho narušujú integritu finančných trhov a dôveru investorov. ${ }^{16}$ Otázkou zostáva, či odhalený kyberútok na akciovú spoločnoste je sám o sebe dôvernou informáciou, ktorú má táto spoločnost̉ zverejnit, resp. sprístupnit.

13 § 230 zákona č. 40/2009 Sb. trestní zákoník. V SR ide o viac skutkov: (§ 247) Neoprávnený prístup do počítačového systému, (§ 247a) Neoprávnený zásah do počítačového systému, (§ 247b) Neoprávnený zásah do počítačového údaja, (§ 247c) Neoprávnené zachytávanie počítačových údajov, (§ 247d) Výroba a držba prístupového zariadenia, hesla do počítačového systému alebo iných údajov, Zákon č. 300/2005 Z. z. Trestný zákon.

14 Zasvätenou osobou môže byt právnická osoba alebo fyzická osoba, ktorá získala dôvernú informáciu. Vid’. § 131 (8) zákona č. 566/2001 Z. z. o cenných papieroch a investičných službách a o zmene a doplnení niektorých zákonov, § 124 (3) zákona č. 256/2004 Sb. o podnikání na kapitálovém trhu.

15 Zneužívanie trhu je pojem, ktorý zahŕňa neoprávnené konanie na finančných trhoch a na účely tohto nariadenia by sa mal chápat tak, že pozostáva $\mathrm{z}$ obchodovania $\mathrm{s}$ využitím dôverných informácií, neoprávneného zverejňovania dôverných informácií a manipulácie s trhom. Takéto konanie bráni úplnej a riadnej transparentnosti trhu, ktorá je predpokladom pre obchodovanie všetkých hospodárskych subjektov na integrovaných finančných trhoch. Vid'. Nariadenie EÚ č. 596/2014 o zneužívaní trhu, rec. 7.

16 Nariadenie EÚ č. 596/2014 o zneužívaní trhu, rec. 23. 
Aby informácia o kyberútoku bola vnútornou informáciou, musí vykazovat nasledujúce znaky, ktoré musia byt’ splnené súčasne: ${ }^{17}$

a) týka sa skutočnosti významnej pre vývoj kurzu či inej ceny finančného nástroja alebo jeho výnosu a mohla by po tom, čo by sa stala verejne známou, významne ovplyvnit kurz, inú cenu alebo výnos finančného nástroja alebo iného nástroja, ktorého hodnota sa odvodzuje od tohto finančného nástroja;

b) nie je verejne známa;

c) je presná.

\subsection{KYBERÚTOK AKO KURZOTVORNÁ INFORMÁCIA}

Z pohl’adu možných následkov, kyberútok nie je odlišný od iného protiprávneho konania smerujúceho $\mathrm{k}$ poškodeniu majetku napadnutej osoby. ${ }^{18}$ Ide o virtualizovaný útok na virtualizované záujmy obete, ktorého následok sa vždy aktualizuje do úbytku aktuálnych hodnôt. Odlišnost̉ je možné vidiet v povahe následkov, nakol'ko samotný kyberútok nemusí byt odhalený vôbec. Medzi najčastejšie následky patrí priama a vyčíslitelná škoda (napr. odcudzenie hodnotných vnútorných údajov), ušlý zisk (napr. zmarená transakcia), zvýšené náklady na kybernetickú ochranu, náklady na konzultačnú činnost’ expertov a právnikov, súdne poplatky a v neposlednom rade nemajetková škoda na povesti. Štatistický sa uvádza, že útok je zistený v priemere až po 205 dňoch. ${ }^{19}$ Tým, že vo virtualizovanom móde je každá informácia potenciálne ubiquitná, jej odcudzenie vo fyzickom zmysle slova nehrozí. Avšak jej zneužitie je d’aleko škodlivejšie. Pri odhalovaní kyberútokov sa bezpečnostní analytici sústredia na kontamináciu alebo narušenie

17 Úřední sdělení Č̌eské národní banky ze dne 18. prosince 2009 o ochraně proti zneužívání trhu a transparenci. Věstník ČNB částka 21/2009 ze dne 23. prosince 2009.

${ }_{18}$ Metodika ČNB uvádza ako príklad kurzotvornej informácie informáciu „o zahájení nebo ukončení soudních, správních nebo rozhodčích řízení, které mají nebo by mohly mít významný vliv na finanční situaci nebo ziskovost emitenta finančního nástroje, např. uložení významné pokuty nebo povinnosti $\mathrm{k}$ náhradě škody významného rozsahu, včetně řízení svýznamným dopadem na reputaci emitenta finančního nástroje apod." pod ktorú je možné následky kyberútoku podradit.

19 BITGLASS. “Where's your data?” experiment. Dostupné z: http://pages.bitglass.com/rs/bitglass/images/BR-Bitglass_Wheres_Your_Data.pdf 
systému podozrivými inštrukciami alebo na chovanie operačného systému a analyzujú sietovú prevádzku. Takýto bezpečnostný incident však ešte nemusí spôsobit priamu škodu. Je preto odlišný od prípadu, kedy sa do archívu spoločnosti vláme zlodej a odcudzí doklady pripravovanej fúzie. Identifikácia chýbajúceho dokladu je jasná a navyše je zrejmé, s akou sumou informácií sa mohol zlodej oboznámit v danom čase a na danom mieste. Kyberútoky sú častokrát koncipované vo vrstvách. Každá vrstva odhaluje d’alšiu vrstvu iného útoku na iné záujmy v napadnutom informačnom systéme. Avšak nie vždy sa podarí vypátrat všetky vrstvy.

Aby kyberútok mal význam pre notifikačnú povinnost', informácia o ňom musí predstavovat kurzotvornú informáciu. Kurzotvorná informácia je taká informácia, ktorá sa priamo dotýka emitenta finančného nástroja, jeho hospodárskej situácie a vyhliadok do budúcnosti, prípadne ktoré sa týkajú práv plynúcich z finančného nástroja. Podl’a usmernenia ČNB „okrem toho ide o značné množstvo informácií, ktoré sa emitenta finančného nástroja, kurzu a pod. týkajú nepriamo - napr. o rastúcej cene ropy, zmene úrokových sadzieb, uzavretie dohody regulovaného trhu s tvorcom trhu o zabezpečenie likvidity $\mathrm{k}$ akciám emitenta finančného nástroja a podobne. [...] Na rozdiel od priamych vnútorných informácií nie je však emitent finančného nástroja povinný nepriame informácie uverejnit. ““ ${ }^{20}$ Preto informácia o kyberútoku ${ }^{21}$ musí splnit nasledujúce podmienky:

- $\quad$ kyberútok je cielený na informačný systém v kompetencii emitenta (priamo alebo nepriamo spojený s emitentom); a

- následok zverejnenia informácie emitentom o prebiehajúcom kyberútoku má sám o sebe potenciál ovplyvnit cenu finančného nástroja (hovoríme o teste cenovej citlivosti na možnú škodu alebo iný následok vyvolaný kyberútokom).

Vyššie uvedený potenciál $\mathrm{v}$ zmysle nariadenia EÚ o zneužívaní trhu je definovaný tak, že následok (ne)zverejnenia má pravdepodobný vplyv na

${ }^{20}$ Ibid. Úřední sdělení ČNB o ochraně proti zneužívání trhu a transparenci, str. 2.

${ }^{21} \S 116$ zákona č. 566/2001 Z. z. o cenných papieroch a investičných službách a o zmene a doplnení niektorých zákonov, § 124 (3) zákona č. 256/2004 Sb. o podnikání na kapitálovém trhu. 
cenu finančného nástroja. ${ }^{22}$ Je zrejmé, že táto pravdepodobnost̉ nebude hraničit s istotou, avšak musí vyzniet dostatočne presvedčivo. Bude posudzovaná individuálne od prípadu k prípadu. Je možné zhrnút, že ak emitent vie o kyberútoku, ktorý prebehol alebo prebieha $\mathrm{v}$ takom rozsahu, že každý riadny hospodár, resp. uvážlivý investor by nadobudol presvedčenie o tom, že takýto útok ovplyvní hodnotu jeho podniku z pohladu jeho majetku, bezpečnosti, ušlého zisku, prípadných sporov alebo povesti, má tento útok pravdepodobný vplyv na cenu.

\subsection{DOSTUPNOSŤ INFORMÁCIE O KYBERÚTOKU}

Informácia o kyberútoku sa stáva verejnou informáciou v čase, ked’ bola sprístupnená tej časti investorov, ktorí sa zhromažd’ovaním informácií tohto typu a ich hodnotením aktívne zaoberajú (napr. sledujú odvetvie, v ktorom pôsobí emitent). ${ }^{23}$ Všeobecne sa považuje informácia za verejne známu, ak je zverejnená voči širokému publiku investorov neurčitého počtu. Ďalej je verejne známa aj taká informácia, ktorá je dostupná súčasným i potenciálnym investorom, aj ked’ nebola zverejnená emitentom včas a riadne. Navyše nie je podstatné, či informáciu uverejnil emitent finančného nástroja alebo či sa stala známou z iných zdrojov. ${ }^{24}$

Môže sa stat, že kyberútok je vykonaný v tichosti a samotná informácia o ňom nemá dôvod preniknút na verejnost. Avšak motívy útočníkov sú rôznorodé. Niektorí predbehnú v informovaní o útoku svoje obete, iní využijú strach zo straty reputácie a pokračujú v tichom vydieraní. Najčastejšie motívy sú vždy kriminálne s úmyslom sa obohatit', čo dokresluje nasledovná štatistika pre rok 2016: ${ }^{25}$

Príkladom medzinárodnej špionáže spolu s kriminálnou činnostou bol masívny kyberútok na spoločnost̉ Sony v roku 2014. Informácia o kyberútoku prenikla na verejnost v novembri 2014, ked’ hackerská skupina Guardians of Peace začala zverejňovat skopírované dáta. Samotná spoločnost

\footnotetext{
22 Článok 7 (1) Nariadenia EÚ č. 596/2014 o zneužívaní trhu.

${ }^{23}$ Ibid. Úřední sdělení ČNB o ochraně proti zneužívání trhu a transparenci, str. 3.

24 Ibid. Úřední sdělení ČNB o ochraně proti zneužívání trhu a transparenci, str. 3.

${ }^{25}$ PASSERI, Paolo. July 2016 Cyber Attacks Statistics. Dostupné z: http://www.hackmageddon.com/2016/08/18/july-2016-cyber-attacks-statistics/
} 


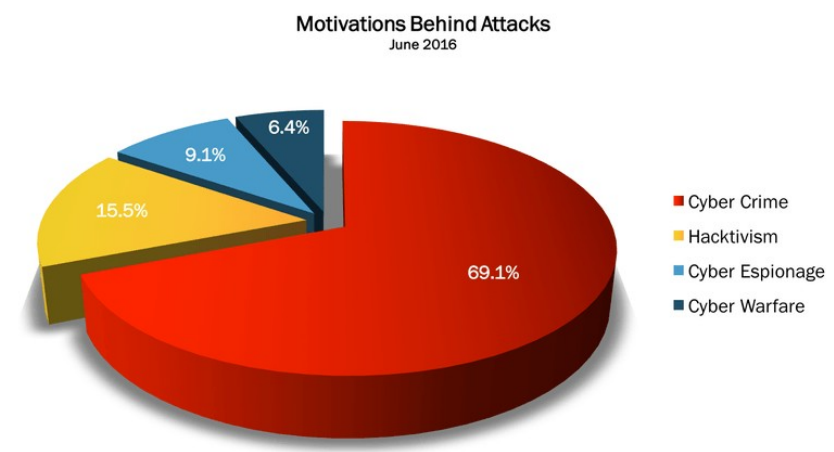

v tomto čase už o útoku vedela, ale zvolila vyčkávaciu taktiku (resp. bola ním zaskočená do takej miery, že nevedela čo robit). ${ }^{26}$

Je zrejmé, že útočník má často v rukách rozhodnutie o tom, či informácia o kyberútoku zostane vnútorná alebo verejná. Sám je viazaný povinnostou mlčanlivosti. Spáchaním trestného činu, t.j. kyberútoku, sa dostal do rovnakého postavenia ako emitent, t.j. do postavenia zasvätenej osoby. ${ }^{27}$ Bolo by však naivné sa domnievat, že útočník po spáchaní kyberútoku dodrží povinnost́ mlčanlivosti. ${ }^{28}$ To má však už aj trestnoprávny rozmer v naplnení niektorých d’alších trestných činov a poškodený musí predvídat takéto konanie. ${ }^{29}$

\subsection{PRESNOSŤ INFORMÁCIE O KYBERÚTOKU}

Presnost̉ informácie je žiadúca najmä z dôvodu, aby sa predišlo nedorozumeniu o tom, či ide o exaktnú informáciu alebo o špekulácie a fámy. Navyše táto presnost’ je naviazaná na potenciál informácie ovplyvnit’ trh

${ }^{26}$ SEAL, Mark. An Exclusive Look at Sony's Hacking Saga. Vanity Fair. Retrieved February 4, 2015. Dostupné z: http://www.vanityfair.com/hollywood/2015/02/sony-hacking-seth-rogen-evan-goldberg

27 Porovnaj § 124(3) ZPK alebo § 131(8)d CPIS.

${ }^{28}$ Insider trading sa vyznačuje tým, že zasvätená osoba poruší nejakú z nasledujúcich povinnosti: nesmie využit vnútornú informáciu k svojmu alebo cudziemu prospechu, nesmie ju oznámit alebo sprístupnit inej osobe a nesmie dávat odporúčania inej osobe na základe znalosti vnútornej informácie. Porovnaj § 124(4) ZPK alebo § § 131(9) CPIS.

${ }^{29}$ V ČR môže íst o trestný čin neoprávněné nakládání s osobními údaji (§ 180 TZ), poškození cizích práv (§ $181 \mathrm{TZ}$ ), porušení tajemství listin a jiných dokumentů uchovávaných v soukromí (§ $183 \mathrm{TZ}$ ), porušení předpisů o pravidlech hospodářské soutěže (porušování obchodního tajemství, § 248(1)h TZ), na SR to bude zrkadlovo najmä ohrozenie obchodného, bankového, poštového, telekomunikačného a daňového tajomstva ( $\$ 264$ TZ). 
s finančnými nástrojmi. Smernica hovorí, že „právna istota pre účastníkov trhu by sa mala zvýšit prostredníctvom užšieho vymedzenia dvoch z prvkov nevyhnutných pre vymedzenie dôvernej informácie, a to presnosti tejto informácie a významnosti jej možného účinku na ceny finančných nástrojov, súvisiacich spotových zmlúv týkajúcich sa komodít alebo dražených produktov založených na emisných kvótach. “" ${ }^{30}$ Kotásek uvádza, že „do istej miery možno dostatočnú záruku presnosti informácií vidiet’ [aj] v tom, že sú vnímané ako informácie, ktorých obsahom sú "skutočnosti", t.j. preukázatel’né a dôkazom prístupné udalosti a stavy vonkajšieho sveta. “ ${ }^{31}$ Žial' z právnej úpravy nemôžeme dovodit to, že by informácia mala byt úplne exaktná. Môžeme sa pýtat, ako vel’mi presná má byt informácia o kyberútoku na to, aby išlo o vnútornú informáciu, ktorá bude mat vplyv na kurz alebo cenu príslušného nástroja.

Odpoved' je možné nájst v prípade Lafont, kde Súdny dvor Európskej únie dovodil, že podmienka presnej informácie nevyžaduje, aby z nej bolo zrejmé, v akom smere bude mat táto informácia vplyv na kurz alebo cenu príslušného nástroja (či bude klesat alebo stúpat). Súd uviedol, že informácia o pláne spoločnosti kúpit významný podiel v inej spoločnosti „môže byt totiž uvážlivým investorom použitá ako súčast̉ základne jeho investičných rozhodnutí. “32 Tento prístup prekonal doteraz platný názor Európskeho orgánu pre trhy cenných papierov (ESMA), podla ktorého „informácia samotná nemusela síce indikovat', $v$ akom rozsahu bude mat vplyv na kurz finančného nástroja, aby však bola presná, musela z nej byt zrejmá aspoň indikácie možného smeru vývoja tohto kurzu. “33 Toto rozhodnutie je v súlade s názorom Kotáska, „či je vôbec nutné klást̉ na vnútorné informácie požiadavku "presnosti" (ked' presné informácie bude [sám] trh schopný vyhodnotit ako informácie s kurzotvornou relevanciou).“"

Pootvorenie dverí pre širší výklad nároku na presnost umožňuje vidiet informáciu o kyberútoku ako vnútornú informáciu poškodeného emitenta.

\footnotetext{
30 Rec. 18 nariadenia EÚ č. 596/2014 o zneužívaní trhu.

31 Ibid. KOTÁSEK, str. 107.

32 Rozsudok SDEÚ vo veci C-628/13 zo dňa 11.3.2015, Jean-Bernard Lafonta proti Autorité des marchés financiers, odst. 33.
} 
Aj ked' ten v čase útoku nevie zhodnotit skutočnú škodu a ušlý zisk spôsobený týmto útokom, musí sa riadit tým, že daná informácia môže byt uvážlivým investorom použitá ako súčast̉ základne jeho investičných rozhodnutí. Napríklad informácia o kyberútoku na spoločnost Sony spôsobila prepad jej akcii na japonskom trhu o $10 \% .^{35} \mathrm{~K}$ podobnému názoru dospeli Arcuri, Brogi a Gandolfi, ktorí skúmali verejne dostupné dáta o kyberútokoch medzi rokmi 1995 až $2012 .^{36}$ Tu však treba spomenút aj opačný názor, ktorý poukazuje na to, že kyberútok ma tendenciu byt zamlčaný, resp. komunikovaný s dlhým časovým odstupom, a preto nemá žiaden kurzotvorný potenciál ako taký. ${ }^{37}$ Osobne zastávam názor prvej skupiny. Je len otázkou času a technologického pokroku, kedy investori dokážu jednoduchým spôsobom zmerat rozsah a výšku škody kyberútoku a bezprostredne na to reagovat. Navyše, nič nie je horšie pre investora technologickej spoločnosti, ak sa až s odstupom času dozvie, že bola terčom kyberútoku. Preto sa d’alšie odborné výskumy odohrávajú aj v oblasti zaistovníctva a poistovacích služieb, ktoré udávajú smer poistnej matematiky a hladajú spôsob ako kvantifikovat kybernetické riziká. ${ }^{38}$

\section{NOTIFIKAČNÁ POVINNOSŤ}

V prípade kyberútoku je možné uvažovat o dvoch existujúcich notifikačných povinnostiach: oznam o porušení ochrany osobných údajov ${ }^{39}$ a oznámenie trestného činu. Podnikanie na kapitálovom trhu priamo takýto

33 ŠOVAR, Ján. Soudní dvưr Evropské unie k insider tradingu: Jak moc nepřesná informace je ještě přesná? Dostupné z: https://www.patria.cz/pravo/2949748/soudni-dvur-evropskeunie-k-insider-tradingu-jak-moc-nepresna-informace-je-jeste-presna.html

${ }^{34}$ Ibid. Kotásek, str. 80.

35 Paul, Monica. Sony hack sends stock down $10 \%$ in past week. Dostupné z: http://money.cnn.com/2014/12/15/investing/sony-stock-hack/

${ }^{36}$ Arcuri, Brogi a Gandolfi. The effect of information security breaches on stock returns: Is the cyber crime a threat to firms? Dostupné z: http://www.efmaefm.org/ OEFMAMEETINGS/EFMA\%20ANNUAL\%20MEETINGS/2014Rome/papers/EFMA2014_' 0408_fullpaper.pdf

${ }^{37}$ Kvochko, Elena. Why Data Breaches Don't Hurt Stock Prices. Harvard Business Review. Dostupné z: https://hbr.org/2015/03/why-data-breaches-dont-hurt-stock-prices

${ }^{38}$ Swiss Re Corporate Solutions joins forces with IBM to offer cyber risk protection. Dostupné z: http://www.swissre.com/corporate_solutions/Swiss_Re_Corporate_Solutions_joins_forces _with_IBM_to_offer_cyber_risk_protection.html 
oznam nepozná, avšak úprava rozlišuje dva druhy notifikácií emitentov: pravidelné notifikačné povinnosti a priebežné (náhodilé) notifikačné povinnosti emitenta. Pravidelne zverejňované informácie (napr. výročné správy) sa v dnešnom digitálnom svete vel'mi rýchlo stávajú obsolentnými. Stávajú sa z nich skôr formálne potvrdenia o predvídanej skutočnosti. Je zrejmé, že investori by neboli schopní urobit svoje rozhodnutia len na základe týchto správ. Priebežne zverejňované informácie sú práve korektívom toho, čo sa stalo medzi pravidelnými hláseniami a zároveň šikovným nástroj na „zneškodnenie“ vnútorných informácií.

Podla súčasného znenia nariadenia EÚ o zneužívaní trhu emitent čo najskôr informuje verejnost̉ o vnútorných informáciách, ktoré sa ho priamo týkajú. Emitent zabezpečí tiež sprístupnenie vnútorných informácií verejnosti, ktoré umožní rýchly prístup a úplné, správne a včasné posúdenie informácií zo strany verejnosti. Emitent nesmie spájat sprístupnenie vnútorných informácií verejnosti s trhovým zviditelňnovaním svojich činností. Navyše, emitent má povinnost̉ uverejnit a uchovat na svojej webovej stránke najmenej pät rokov všetky vnútorné informácie, ktoré je povinný sprístupnit verejnosti. Vnútorné informácie uverejňované emitentom by sa mali šírit tak, aby k nim bol zaistený neuprednostňujúci, lahký a bezodplatný prístup. To znamená, že rovnaká informácia by mala byt zároveň zaslaná (v elektronickej podobe) Českej Národnej Banke, príp. organizátorom regulovaných trhov, na ktorých sú finančné nástroje emitenta prijaté na obchodovanie, a zároveň uverejnená $\mathrm{v}$ obvyklom formáte, t.j. tak, aby všetkým investorom boli poskytnuté informácie obsahovo zhodné a v rovnakom čase. Nesplnenie notifikačnej povinnosti je prísne sankcionované dozorným orgánom. ${ }^{40}$

Americká SEC už v roku 2011 prijala (nezáväzné) odporúčanie o tom, ako by mal postupovat emitent $\mathrm{v}$ prípade informácie o kybernetickom

\footnotetext{
${ }^{39}$ Článok 33 (Oznámenie porušenia ochrany osobných údajov dozornému orgánu) a článok 34 (Oznámenie porušenia ochrany osobných údajov dotknutej osobe) nariadenia Európskeho parlamentu a rady (EÚ) 2016/679 z 27. apríla 2016 o ochrane fyzických osôb pri spracúvaní osobných údajov a o volnom pohybe takýchto údajov, ktorým sa zrušuje smernica 95/46/ES (všeobecné nariadenie o ochrane údajov).

${ }^{40}$ Vid' článok 30 nariadenie EÚ č. 596/2014 o zneužívaní trhu.
} 
útoku. ${ }^{41}$ Kyberútok už dávno nie je len záležitostou IT oddelenia, ale stal sa vecou záujmu akcionárov, investorov a širšej verejnosti. Zaujímavostou je, že notifikačná povinnost' v USA sa nevztahuje len na samostatný útok, ale pokrýva aj hrozbu útoku a vytvára rámec pre cybersecurity governance: ${ }^{42}$

Registrants should disclose the risk of cyber incidents if these issues are among the most significant factors that make an investment in the company speculative or risky [...] In determining whether risk factor disclosure is required, we expect registrants to evaluate their cybersecurity risks and take into account all available relevant information, including prior cyber incidents and the severity and frequency of those incidents.

Emitent (registrant) v USA musí pred zverejnením informácie o kyberútoku posúdit pravdepodobnost’ takého incidentu. Musí zohl'adnit kvantitatívne a kvalitatívne hladisko hroziaceho rizika, d’alšie potencionálne náklady na jeho odstránenie a iné aspekty súvisiace so zneužitím vnútorných informácií. Tieto povinnosti logicky tlačia povinné osoby k tomu, aby prijali najvyššie možné preventívne opatrenia voči kyberútokom. Emitent má taktiež povinnost̊ identifikovat', ktoré jej oblasti podnikania sú rizikové z pohl'adu možného kyberútoku. Adekvátne opatrenia sú posudzované samotným SECom. Už len zanedbanie prijatia takéhoto opatrenia môže podliehat enormným sankciám. V čase ohrozenia alebo odhalenia nestačí nahlásit kyberútok, ale emitent musí preukázat taktiež všetky reaktívne kroky.

Na záver sa je možné spýtat', čo v prípade, že by bol kyberútok odvrátený. Má emitent rovnakú informačnú povinnosț? Tu sa je možno inšpirovat znením všeobecného nariadenia o ochrane údajov v prípade notifikačnej povinnosti o porušení osobných údajov, kde sa oznámenie nevyžaduje, ak prevádzkovatel' prijal primerané technické a organizačné ochranné opatrenia. ${ }^{43} \mathrm{~V}$ prípade kyberútoku by malo íst’ o také následné opatrenia,

${ }^{41}$ Ibid. SEC, CF Disclosure Guidance.

${ }^{42}$ Podobne ako tomu je pri inštitúte e-discovery hold v prípade hroziaceho súdneho sporu, kedy strana, ktorá môže byt̉ zažalovaná, má povinnost uchovávat' všetky elektronické informácie pre budúci spor.

43 Článok 34 nariadenia Európskeho parlamentu a rady (EÚ) 2016/679 (všeobecné nariadenie o ochrane údajov). 
ktorými sa zabezpečí, že riziko zneužitia informácie o kyberútoku pravdepodobne už nebude mat vplyv na kurz, cenu alebo výnos finančného nástroja.

\section{5. ČASOVÝ ASPEKT}

Česká a slovenská úprava hovorí o povinnosti „bezodkladného“ uverejnenia. Ide o primeraný časový úsek, v ktorom je emitent finančného nástroja schopný uverejnit vnútornú informáciu za daných okolností a pri svojom bežnom chode. ${ }^{44} \mathrm{Za}$ nezverejnenie zodpovedá priamo emitent. Domnievam sa, že emitent musí informovat’ o kyberútoku okamžite po tom, čo sa dozvedel o jeho technických znakoch, ktoré sú dostatočne zrozumitel'né pre uvážlivého investora a súčasne boli splnené všetky kritéria vnútornej informácie.

Uverejnenie informácie možno odložit v prípade závažných dôvodov na strane emitenta. ${ }^{45}$ Avšak musí byt splnená podmienka, že nesprístupnením informácie nebude verejnost̉ klamaná (pravdepodobne nebude zavádzaná) a emitent je schopný zabezpečit dôvernost’ týchto informácií. Zabezpečenie dôvernosti informácie o kyberútoku na strane emitenta je len zdanlivé riešenie. Ako bolo spomenuté vyššie, útočník, hoci v postavení zasvätenej osoby, je nekontrolovatel’ným elementom v šírení informácie, a preto túto povinnost' emitent nemôže takmer nikdy objektívne splnit. Domnievam sa, že odloženie informácie o zistenom kyberútoku je možné len v prípade, ak by došlo k zadržaniu všetkých útočníkov orgánmi činnými v trestnom konaní, súčasne by nedošlo ešte $\mathrm{k}$ rozšíreniu tejto informácie v relevantnom okruhu investorov a emitent bol o tejto skutočnosti riadne informovaný.

${ }^{44}$ Ibid. Úřední sdělení ČNB o ochraně proti zneužívání trhu a transparenci, str.8, porovnaj nález Ústavného súdu ČR sp. zn. IV. ÚS 314/05 zo dňa 15. augusta 2005 a rozsudok Najvyššieho správneho súdu ČR sp. zn. 3 As 2/2008 - 152 zo dňa 2. apríla 2008.

${ }^{45}$ O odložení musí emitent informovat dozorný orgán, t.j. ČNB alebo NBS, a to vrátane uvedenia dôvodov pre odloženie a obsahu odkladané informácie. Článok 17(3) Nariadenia EÚ č. 596/2014 o zneužívaní trhu. 


\section{ZÁVER}

Na základe vyššie uvedeného je možné dospiet $k$ záveru, že emitent má povinnost bezodkladne informovat o prebiehajúcom alebo dokonanom kyberútoku relevantnú verejnost', ak sú splnené podmienky kladené na kvalitu vnútornej informácie. Takéto oznámenie by malo obsahovat jasne a jednoducho formulovaný opis povahy narušenia informačného systému emitenta a základné informácie o prijatých opatreniach. ${ }^{46}$ Vzhladom na to, že v súčasnosti právna úprava $\mathrm{v}$ tejto oblasti absentuje a konkrétne odporúčania alebo usmernenia neexistujú, posúdenie tejto informačnej povinnosti emitenta bude v kompetencii jeho dozorných orgánov a bude v konečnom dôsledku závisiet od rozhodovacej činnosti súdu.

\section{POUŽITÁ LITERATÚRA}

\subsection{LITERATURA}

[1] HONG, N. a Sidel, R., Hackers Breach Law Firms, Including Cravath and Weil Gotshal. The Wall Street Journal. Marec 2016. Dostupné z: http://www.wsj.com/articles/hackersbreach-cravath-swaine-other-big-law-firms-1459293504

[2] What lies behind the JPMorgan Chase cyber-attack. The Economist. November 2015. Dostupné z: http://www.economist.com/news/business-and-finance/21678214-criminal-economy-developing-faster-lawful-one-can-defend-itself-what-lies-behind

[3] Division of Corporation Finance, Securities and Exchange Commission, CF Disclosure Guidance. 2011. Dostupné z: https://www.sec.gov/divisions/corpfin/guidance/cfguidancetopic2.htm

[4] KOTÁSEK, Josef. Ochrana vnitřních informací. Brno: Tribun EU, 2008. 255 s. ISBN 97880-7399-355-9.

[5] SCHEPPELE, Kim Lane. "It's Just Not Right": The Ethics of Insider Trading. Law and Contemporary Problems, Vol. 56, No. 3, Modern Equity, Summer, 1993.

[6] BITGLASS. "Where's your data?" experiment. Dostupné z: http://pages.bitglass.com/rs/bitglass/images/BR-Bitglass_Wheres_Your_Data.pdf

[7] PASSERI, Paolo. July 2016 Cyber Attacks Statistics. Dostupné z: http://www.hackmageddon.com/2016/08/18/july-2016-cyber-attacks-statistics/

46 Inšpiráciu tu môže byt použitie slovníka „Common Vulnerabilities and Exposures (CVE®)“. Vid'. https://cve.mitre.org/about/ 
[8] SEAL, Mark. An Exclusive Look at Sony's Hacking Saga. Vanity Fair. Retrieved February 4, 2015. Dostupné z: http://www.vanityfair.com/hollywood/2015/02/sony-hacking-seth-rogenevan-goldberg

[9] Paul, Monica. Sony hack sends stock down $10 \%$ in past week. Dostupné z: http://money.cnn.com/2014/12/15/investing/sony-stock-hack/

[10] Arcuri, Brogi a Gandolfi. The effect of information security breaches on stock returns: Is the cyber crime a threat to firms? Dostupné z: http://www.efmaefm.org/OEFMAMEETINGS/EFMA\%20ANNUAL\%20MEETINGS/2014Rome/papers/EFMA2014_0408_fullpaper.pdf

[11] Kvochko, Elena. Why Data Breaches Don't Hurt Stock Prices. Harvard Business Review. Dostupné z: https://hbr.org/2015/03/why-data-breaches-dont-hurt-stock-prices

[12] Swiss Re Corporate Solutions joins forces with IBM to offer cyber risk protection. Dostupné z: http://www.swissre.com/corporate_solutions/Swiss_Re_Corporate_Solutions_joins _forces_with_IBM_to_offer_cyber_risk_protection.html

\subsection{POUŽITÉ PRÁVNE PREDPISY A SÚDNE ROZHODNUTIA:}

[13] Cal. Civ. Code 1798.82 and 1798.29. Dostupné z: http://www.leginfo.ca.gov/pub/0102/bill/sen/sb_1351-1400/sb_1386_bill_20020926_chaptered.pdf

[14] Rozsudok SDEÚ vo veci C-628/13 zo dňa 11.3.2015, Jean-Bernard Lafonta proti Autorité des marchés financiers,

[15] Úř̌ední sdělení Č̆eské Národní Banky ze dne 18. prosince 2009 o ochraně proti zneužívání trhu a transparenci. Věstník ČNB částka 21/2009 ze dne 23. prosince 2009.

[16] Zákon č. 256/2004 Sb. o podnikání na kapitálovém trhu.

[17] Zákon č. 566/2001 Z. z. o cenných papieroch a investičných službách a o zmene a doplnení niektorých zákonov.

[18] Zákon č. 429/2002 Z. z. o burze cenných papierov v znení neskorších predpisov.

[19] Nariadenia Európskeho parlamentu a rady (EÚ) č. 596/2014 zo 16. apríla 2014 o zneužívaní trhu (nariadenie o zneužívaní trhu) a o zrušení smernice Európskeho parlamentu a Rady 2003/6/ES a smerníc Komisie 2003/124/ES, 2003/125/ES a 2004/72/ES.

[20] Zákon č. 181/2014 Sb. o kybernetické bezpečnosti a o změně souvisejících zákonů.

[21] Zákon č. 40/2009 Sb. Trestní zákoník.

[22] Zákon č. 300/2005 Z. z. Trestný zákon.

Toto dílo lze užít $v$ souladu s licenčními podmínkami Creative Commons BY-SA 4.0 International (http://creativecommons.org/licenses/by-sa/4.0/legalcode). 